\section{"Lipoblastoma-like" lipoatrophy induced by human insulin: morphological evidence for local dedifferentiation of adipocytes?}

Dear Sir,

The frequency of lipoatrophy greatly diminished with the wide availability of monocomponent insulins and later lipoatrophy became a clinical curiosity in diabetic patients treated with human insulin. There are some case reports about patients with lipoatrophy initially treated with animal insulin and subsequently human insulin [1-3]. Lipoatrophy in diabetic patients treated exclusively with human insulin is an extremely rare clinical condition, only a few cases have been described previously $[1,4,5]$. Such a case was designated as the second observation in the literature in 1996 [5].

The pathomechanism of lipoatrophy is not clearly understood. It has been earlier hypothesised that insulin-induced lipoatrophy is the consequence of a local immune reaction to insulin crystals. This explanation was corroborated by histological findings of lipoatrophic areas. In 1996, the clinical history of a patient with extensive lipoatrophic areas was published. This patient was treated with porcine and subsequently human insulins and a local hyperproduction of TNF- $\alpha$ was shown by in vitro studies. Although no histological investigation had been made it was hypothesised that the dedifferentiation of the adipocytes of the subcutaneous tissue secondary to insulin injections was induced by local hyperproduction of TNF- $\alpha$ from macrophages [3].

We observed lipoatrophic areas in a female patient who had been treated exclusively with human insulin since the manifestation of the diabetes. A lipoblastoma-like alteration as a sign of dedifferentiation of adipose tissue was found at histological examination. These findings could be evaluated as morphological evidence for the local hyperproduction of TNF- $\alpha$ suggested earlier.

A 14-year-old adolescent girl experienced typical clinical signs of diabetes mellitus at age 11 and subsequently treatment with human insulin (Actrapid $\mathrm{HM}_{\mathrm{ge}}$ penfill before main meals and Insulatard $\mathrm{HM}_{\mathrm{ge}}$ penfill twice daily for basal insulin supplementation) was initiated. Some months later the patient wanted to change her pens and therefore, insulins were changed for Humulin R cartridge (daily dose 12 IU) and Humulin $\mathrm{N}$ cartridge (daily dose $24 \mathrm{IU}$ ). At age 13 the patient experienced some "holes" at different sites of insulin injection. The pens had been used correctly, the insulin injection sites were regularly rotated and there was no excessive reuse of insulin needles. Lipoatrophic areas occurred, however, on the abdominal wall, buttock, thigh and upper arm. The patient was admitted to our department at age 14.

We observed at examination (BMI $16.6 \mathrm{~kg} / \mathrm{m}^{2}$ ) an adolescent girl without any remarkable physical alterations except typical lipoatrophic areas (size $3 \times 3 \mathrm{~cm}$ ) at insulin injection sites. Type I (insulin-dependent) diabetes mellitus was documented by laboratory findings $\left[\mathrm{HbA}_{1 \mathrm{c}}: 9.1 \%\right.$ (normal range $4.0-6.0 \%)$, daily blood glucose between $3.5 \mathrm{mmol} / 1$ and $17.1 \mathrm{mmol} / \mathrm{l}$, fasting serum C peptide $0.06 \mathrm{pmol} / \mathrm{ml}$, serum islet cell cytoplasmatic antibody (ICA) 10.0 JDFU, GAD-antibody (GADA) $2.4 \mathrm{U} / \mathrm{ml}$, tyrosine-phosphatase antibody (IA2): 13.7 $\mathrm{U} / \mathrm{ml}$. No signs of late specific complications were found by funduscopy and, in addition, normoalbuminuria and normal

Corresponding author: György Jermendy, MD, 3rd Medical Department, Bajcsy-Zsilinszky Hospital, Maglódi út 89-91, Budapest, Hungary, H-1106 serum creatinine values as well as normal values at investigation with calibrated tuning forks were documented.

To explain the possible cause of lipoatrophy, secondary to human insulin, intracutan tests with human insulins were done but no signs of allergy were found. Moreover, results of epicutan tests with common atopic allergens were also negative. The values of serum immunoglobulins were normal (IgG $13.7 \mathrm{~g} / \mathrm{l}, \operatorname{IgA} 1.25 \mathrm{~g} / \mathrm{l}, \operatorname{IgM} 1.63 \mathrm{~g} / \mathrm{l})$ and the value of serum TNF- $\alpha$ was also normal $(1.2 \mathrm{ng} / \mathrm{ml})$. Insulin-specific soluble IgG antibody titre (1:32) and insulin-specific soluble IgE antibody titre (1:2) were increased. In accordance with the latter findings serum insulin-binding capacity was also increased [57\% (normal value $\leq 10 \%)]$. An excision of a lipoatrophic area at the buttock was carried out. On histological examination the structure of epidermis was normal. Neither signs of local immune mechanisms nor inflammatory cell infiltrates could be found in the dermis. Adipocytes with hyperchromatic, enlarged nuclei and smaller cytoplasm resembling lipoblasts and proliferation of capillaries were, however, documented in the subcutis. The histological findings were characteristic of benign lipoblastoma seen in infancy. In immunohistological investigations with polyclonal and monoclonal S-100 proteins, adipocytes were positive whereas the CD-31 reaction was positive at sites of capillary proliferation. No signs of proliferation were documented by Ki-67 reaction in the lipoblastoma-like area. The histological diagnosis was that there were lipoblastoma-like alterations of the subcutis at the site of the former insulin injections.

The patient was switched to insulin lispro (Humalog cartridge), given prandially. The basal insulin supplementation with Humulin N cartridge was not changed apart from modification of doses. Humalog was given by pen in the areas of the thighs which were free from lipoatrophy. At discharge the insulin regime was as follows: Humalog at breakfast 11-13 IU, at lunch 7-9 IU and at dinner 4-6 IU, Humulin N at breakfast $16 \mathrm{IU}$ and bedtime 9 IU. Blood glucose was monitored at home and actual insulin doses were modified according to the results obtained. During the follow-up of 1 year the metabolic control improved $\left(\mathrm{HbA}_{1 \mathrm{c}}: 7.9-8.1 \%\right)$ and no further lipoatrophic areas were observed. In addition, the former lipoatrophic areas moderately regressed.

Although we can only speculate on the pathomechanism of lipoatrophy in the patient, dedifferentiation of adipocytes (lipoblastoma-like alterations) was documented by histological investigations. These findings could be evaluated as morphological evidence for the local hyperproduction of TNF- $\alpha$ suggested earlier $[3,6]$. It is not known whether alterations in PPAR- $\gamma$ (peroxisome proliferator-activated receptor- $\gamma$ ) or UCP2 (uncoupling protein 2) were involved in the local process $[7,8]$.

Immunological consequences of previous human insulin treatment were documented by high insulin-specific soluble $\mathrm{IgG}$ and $\mathrm{IgE}$ antibody titre. It is, however, unlikely that these alterations could have resulted in local cutaneous complications. In addition, no clinical signs of immunogenic insulin resistance were observed in the patient.

A patient with lipoatrophy was treated exclusively with human insulin from the onset of diabetes at the age of 11 years. She was then, at the age of 14 years, treated with Humalog which did not induce lipoatrophy during 1 year of follow-up. Whatever the exact pathomechanism of lipoatrophy is, Humalog due to its characteristic pharmacokinetics can absorb rapidly from subcutaneous tissue and consequently, subcutaneous adipocytes spend less time exposed to the local "lipoatrophic" side effect of insulin used in susceptible patients.

Yours sincerely, G. Jermendy, J. Nádas, Z. Sápi 


\section{References}

1. Igea JM, Escalada J, Cuevas M, Sainz T, Barrio R (1992) Lipoatrophy secondary to human insulin treatment. Immunological study. Allergol Immunopathol 20: 173-175

2. Chantelau E, Reuter M, Schotes S, Strake AAR (1993) A case of lipoatrophy with human insulin-therapy. Exp Clin Endocrinol Diabetes 101: 194-196

3. Atlan-Gepner C, Bongrand P, Farnarier C et al. (1996) Insulin-induced lipoatrophy in type 1 diabetes. A possible tumor necrosis factor- $\alpha$ mediated dedifferentiation of adipocytes. Diabetes Care 19: 1283-1285

4. Page MD, Bodansky HJ (1992) Human insulin and lipoatrophy. Diabetic Med 9: 779
5. Jaap AJ, Horn HM, Tidman MJ, Walker JD (1996) Lipoatrophy with human insulin. Diabetes Care 19: 1289-1290

6. Petruschke T, Hauner H (1993) Tumor necrosis factor- $\alpha$ prevents the differentiation of human adipocyte precursor cells and causes delipidation of newly developed fat cells. J Clin Endocrinol Metab 76: 742-747

7. Auwerx J (1999) PPAR $\gamma$, the ultimate thrifty gene. Diabetologia 42: 1033-1049

8. Strobel A, Siquier K, Zilberfarb V, Strosberg AD, Issad T (1999) Effect of thiazolidinediones on expression of UCP2 and adipocyte markers in human PAZ6 adipocytes. Diabetologia 42: $527-533$ 